\title{
WILLIAM KENRICK, EIGHTEENTH CENTURY SCOURGE AND CRITIC
}

\author{
BY PAUL FUSSELL, JR.
}

Paul Fussell, JR., a graduate of Pomona College who holds a doctorate from Harvard University, taught at Connecticut College before coming to Rutgers as Assistant Professor of English in 1955. A specialist in English literature of the eighteenth century, he will spend $1957-58$ as Fulbright Lecturer at the University of Heidelberg.

$\mathbf{R}$ EPOSING forlornly in the Special Collections of the Rutgers University Library, its contemporary calf binding broken from long, hard use (or perhaps, as I should be happier to think, from the anger of some eighteenth century reader), is a small and pathetic I6mo. of I7I pages, published in London in I760. Once the occasion of embarrassment and rage in eighteenth century London, this little book, all passion spent now, suggests only faintly today its original context of violence, sarcasm, libel, and masochistic gaiety.

The book is titled Remarkable Satires: The Causidicade [which is not, for some reason, even in the volume], The Processionade, The Triumvirade, The 'Piscopade, The Porcupinade, The Scandalizade, and The Pasquinade, with Notes Variorum. Sometimes found with the main title Satires on Several Occasions, this work seems to be the result of the collaborative efforts of Macnamara Morgan and William Kenrick. To Morgan may be ascribed The Processionade, to Morgan and Kenrick together The Scandalizade, and to Kenrick both The 'Piscopade and The Pasquinade. All of these pieces are rugged heroic-couplet satires in the Dunciad tradition, and, like their more famous ancestor, they would require (were they worth it) elaborate annotation to make their satiric targets recognizable to the modern reader. But even through the haze of two centuries, enough of the original vigor of these satires remains to evoke images of the unique strain of anger, frustration, and bitterness which is the stigma of an important side of the English eighteenth century.

About Macnamara Morgan of the pleasant name I shall regret- 
fully say nothing here, for William Kenrick, his collaborator in the Remarkable Satires, is more interesting and representative. This ragged and drunken satirist, critic, playwright, poet, perpetualmotion expert, Shakespearian, small philosopher, and lexicographer was during the last half of the eighteenth century perhaps the leading contender for the position of the most despised citizen of the republic of letters. But gleaming through the rather ill-smelling murk of Kenrick's career shine a few flashes of an admirable, if frenzied, astuteness which justify a brief survey of the life and the literary criticism of this constitutionally angry man.

The only extant portrait of Kenrick, made at the age of thirtysix, presents a slightly puffy and self-assured figure staring glumly out of a frame embellished by the works of Locke, Milton, and Shakespeare, and by musical and scientific instruments of all kinds; ${ }^{1}$ this portrait, symbolizing as it does Kenrick's versatility and his irrepressible desire to achieve lasting recognition in a great number of areas, might suggest that Kenrick's first misfortune was to have been born just about a century too late.

Kenrick was born sometime between 1729 and $1730^{2}$ in Watford, Hertfordshire, the son of a scalemaker; he managed to finish a grammar school education, which seems to have included the study of Greek and Latin, and the reading of the works of Newton, Locke, Hume, Descartes, Pope, and Bolingbroke. Impatient of continuing his formal education, he travelled on the continent, particularly in Holland, until he was eighteen or nineteen; during these early travels (which may have included activity as a spy for England) Kenrick gained a remarkable facility with the modern European languages which was to be one of his greatest literary assets when he finally settled down to hack-writing in London. Upon his return from Holland around I 748, Kenrick's father apprenticed him to a maker of brass rulers, a fact of which Kenrick's later enemies never ceased to remind him. The proud, travelled, and more than commonly learned young man, chafing under the restrictions of an ap-

\footnotetext{
${ }^{1}$ Reproduced in George E. Brewer, Jr., "The Black Sheep of Grub Street: William

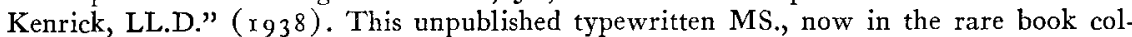
lection of the Boston Public Library, is my main source for biographical facts about Kenrick.

${ }^{2}$ See Paul Fussell, Jr., and George E. Brewer, Jr., "The Birth Date of William Kenrick," Notes and Queries, CXCV (February 4, 1950), 5 1-52.
} 
prenticeship to a mechanical trade, soon contrived his revenge on the world in the form of his first verse satire, attacking the church, the reigning wits, and the stage; Kenrick's weak reforming instincts were generally subordinate to what has been called a "vivid intention to inflict punishment," and in this first youthful iconoclastic broadside, Kenrick takes special care to hold contemporary theatrical audiences up to painful ridicule.

Sometime before 1750 , Kenrick managed to release himself from the apprenticeship which he considered a degrading confinement of his soaring powers, and, in company with several other young men, he set out for Grub Street, like Samuel Johnson, to make his fortune in literature. Together with these other unidentified young reformers and satirists, Kenrick founded a Menckenesque journal in London; The Kapélion; or, Poetical Ordinary (London, I 750-I75I) is just what one might expect. Kenrick assisted in the publication of this painfully self-conscious magazine for about six months, and then, with characteristic impatience, decided to break loose and seek the patronage of both nobility and gentry. In an effort to convince the middle-classes that they should support him, he published the Old Woman's Dunciad, ${ }^{5}$ a worthless neo-Popean satire; upon the failure of the middle-class reading public to pay its respects to young genius, Kenrick turned his attention to the crown in $A$ Monody to the Memory of his Royal Highness Frederick Prince of Wales (London, I 75I - - a crude imitation of Gray's "Elegy," published the year before. Failing to secure the promise of any sort of livelihood from his poetical talents, Kenrick, always desperately short of ready money, next tried his hand at theological disputation in The Grand Question Debated, or An Essay to prove that the Soul of Man is not, neither can be, Immortal (London, I75I). Writing under the pseudonym of "Ontologos," Kenrick (in reality a pious creature throughout his life) sought to agitate enough of a controversy to enable him to reply to his attackers, and thus squeeze a bit more out of the booksellers. Since a silence which must have been humiliating greeted the book, he was forced, he thought, to undertake an answer himself, and later in the same year which saw the publication of $T$ he

\footnotetext{
${ }^{3}$ The Town: A Satire (London, 1748). $\quad{ }^{4}$ Brewer, p. I 3.

5 "By Mary Midnight" (London, I75I). See Richmond P. Bond, "A Triple Burlesque," $M L N$, XLIII (1928), 312-315.
} 
Grand Question Debated, London readers were comforted by an anonymous and bitter refutation of the impious work, under the title A Reply to the Grand Question Debated (London, I75I). These first ventures of Kenrick's into prose emphasize his extraordinary capacity for writing under disguises, a Grub Street practice which he never entirely abandoned.

Indeed, as George E. Brewer has said, "the essential flair of Kenrick's mind was theatrical"; ${ }^{*}$ it is no wonder to find him, in 1752 , disappointed by his poses in both poetry and prose, eagerly assuming the rôle of playwright. His first farce, Fun: A paroditragicomical Satire (London, I 752), was never acted; in it, Kenrick, while appropriating for his own use much of the manner of Fielding's farces, attacks Fielding at every opportunity. In a prologue to this hasty and disorderly production, we find the following edifying couplet:

\section{... I disdain old Aristotle's rules, \\ That tie down scribblers, limit none but $F_{\text {ools. }}{ }^{7}$}

This first play of Kenrick's was suppressed by the Lord Mayor, perhaps at the instigation of some of Fielding's political partisans, and the frustrated and hungry playwright returned to satirical verse, writing in 1753 The Pasquinade, with notes Variorum, an imitation of the Dunciad, complete with facetious footnotes and an enthroned Goddess of Dullness; the poem attacks, maliciously but also quite wittily, Dr. John Hill's "indolent waddle," Richardson, Smollett, and the collection-mad botanical and biological virtuosi of the Royal Society. In the notes to this anonymous satire, reprinted in the Rutgers University copy of Remarkable Satires, Kenrick attempts to stimulate some interest in his earlier Grand Question, which was apparently moving very slowly across the booksellers' counters. Kenrick's habitual love of assuming disguises gave him ample opportunity to make use of this form of self-advertisement during his whole career. A Boswellian self-description in another note is of some interest:

[Kenrick is] a very young poet, and a pretender to almost all kinds of writing. . . . It is the misfortune of this youth, that, unless he finishes what he goes about in a day or two, the world never sees it afterwards. . . His Old Woman's Dunciad is an extraordinary instance of that impetuosity of Genius,

$$
{ }^{6} \text { Page 32. } \quad{ }^{7} \text { Page v. } \quad{ }^{8} \text { Page } 4 .
$$


which tho' redounding little to his honour, is very offensive to his adversaries. ... He is also the author of innumerable poetical, philosophical, and political pieces. ... It is no wonder that he should be so indefatigable a writer, as he ... never takes any pains. ${ }^{\circ}$

In I753, Kenrick's "natural talent for persiflage"10 and literary disguise again manifested itself in The Whole Duty of Woman, one of his most bizarre performances. Here, the "authoress," coyly confessing herself a fallen woman and "a persuader of the fair sex to virtue, ${ }^{11}$ proceeds to demonstrate her persuasive powers in hundreds of moral aphorisms, all revealing, in their use of verbal parallelism, a marked stylistic debt to the Song of Solomon and the Proverbs. A few examples will suffice to show that the whole performance, coming from Kenrick, was "a masterpiece of hypocrisy": ${ }^{12}$

Happy the days ... while the bosom is a stranger to deceit.

Hear then, $\mathrm{O}$ daughter of Britain. $\mathrm{O}$ fairest of the fair among women! let my precepts be treasured in thy bosom, and walk in the ways of my counsel; so shalt thou shun the thorn of reproach, more keen than the bite of the asp, more venomous than the sting of the scorpion.

Avoid, therefore, vain glory and self conceit.

Be not fond of reproving, for she who assumeth the place of a censor, will be esteemed arrogant. ${ }^{13}$

The work, despite (or, perhaps, because of) its slipshod craftsmanship and pretentious piety, was extremely popular: it had gone through sixteen editions by $\mathrm{I} 83 \mathrm{I}$, nine of the editions supplying the demand from the United States of America. That no irony leaks through the surface of the style is some indication of Kenrick's talents as a stylist and as a literary impersonator. ${ }^{14}$

But even the moderate success of The Whole Duty of Woman was apparently insufficient to provide for Kenrick's financial needs, for, in I 754, we find Kenrick, the vendor of moral aphorisms, in debtor's prison; never a man to waste his time in idleness, however, Kenrick spent his year behind bars in writing a series of philosophical verse epistles which he published upon his release, and revised and republished in 1758 as Epistles Philosophical and Moral. The revised

\footnotetext{
${ }^{9}$ Page $20 . \quad{ }^{10}$ Brewer, p. $73 . \quad{ }^{11}$ Page 4.

${ }^{12}$ Honor McCusker, "Dr. Kenrick of Grub Street," More Books, XIV (I939), 4.

13 Pages 8, 9, I 7, 24.

${ }^{14}$ See Paul Fussell, Jr., "William Kenrick's 'Courtesy' Book," PMLA, LXVI ( I95 I), $538-540$.
} 
version contains eight long verse letters to "Lorenzo" in octosyllabic couplets, which prove, in Kenrick's hands, strikingly monotonous for such long flights. The epistles treat a variety of philosophical subjects, but Kenrick's most important point is the inefficacy of reason in apprehending the nature of God, or indeed of dealing in any way with matters that are properly the concern of "faith." Kenrick also places himself in an empirical, common-sense position when he attacks paradoxical schemes of reasoning and elaborate philosophical structures. As we shall see later, Kenrick's primary tenet of judicial literary criticism was this same reliance on universal common-sense as opposed to complex critical schemes not founded on a publicly-observable "nature." Kenrick's E pistles were well received by the contemporary reviewers, and achieved moderate circulation during his lifetime.

Despite his few slight successes before I 758, Kenrick found himself unable to maintain himself independently, and, in that year, he was forced to take a position as reviewer under Ralph Griffiths, the proprietor of the Monthly Review. For eight years Kenrick turned out reviews for Griffiths, working mainly on both translated and untranslated foreign books.

Kenrick had hardly settled down to the tedious routine of grinding out reviews for Griffiths when he began to search about for some means of regaining his precious independence; Rousseau's publication of Julie ( $176 \mathrm{I}$ ) gave Kenrick his opportunity, and he immediately embarked on a translation, issuing it as Eloisa the same year. This, Kenrick's first venture into translation, was undertaken in a spirit typical of his pride and impetuosity. In his preface to the translation, Kenrick announced that the difficulty of Rousseau's prose had intrigued him into trying his hand at a translation, and he plainly stated his intention of improving on the original wherever he found himself tempted..$^{15}$ Kenrick's translation, while not without some merit, is exceedingly free $;^{16}$ he occasionally found it necessary to add whole sentences for the sake of clarity or emphasis. Although Kenrick's desire not to be caught in any act of servility, even, apparently, the "servility" of a literal translation, results in both dangling clauses

\footnotetext{
${ }^{15}$ See James H. Warner, "Eighteenth-Century English Reactions to the Nouvelle Héloüse," PMLA, LII (1 937), 803-8 I 9.

${ }^{16}$ See Richard B. Sewall, "William Kenrick as Translator and Critic of Rousseau," $P Q, \mathrm{XX}$ (194I), 58-68; and Warner, p. 807.
} 
and formless sentences, one modern scholar has said that Kenrick's translation of Rousseau is "perhaps the most worthy accomplishment of a troublesome career." " Kenrick's translation was certainly popular, and its popularity was perhaps as much due to the efforts of Kenrick the reviewer as of Kenrick the translator, for Kenrick's position on the Monthly Review gave him the chance to puff his own work anonymously, an opportunity which few Grub Streeters would constitutionally have been able to resist. His review of his own translation of Eloisa concludes thus:

... we cannot close this article without acknowledging, how agreeably we were surprised to find a work, written in so difficult and singular a style, so speedily and elegantly translated into our own language. ... the Translator has, very judiciously, and with good taste, improved on his original, where it seemed rather defective. ${ }^{18}$

In I 763, Kenrick translated Rousseau's Emile, titling the work Emilius and Sophia; or a New System of Education. In his review of his own translation of this work, after remarking that Rousseau has been fortunate in falling into the hands of a good translator, Kenrick goes on to rationalize his hasty method which had resulted in an extremely free translation:

It is not a minute resemblance in the matter of pencilling, but the bolder touches and animated strokes of the piece that constitute the merit of a copy. ${ }^{19}$

In the same year, Kenrick also translated Rousseau's $A$ Treatise of the Social Contract, which he followed, in I 764, by a translation of Voltaire's Treatise of Religious Toleration; the appearance in 1767 of Kenrick's collected Rousseau translations as the Miscellaneous Works of J.J. Rousseau (in five volumes) concluded Kenrick's work with translation.

Around I 763 or I 764 , Kenrick, who had been an amateur Shakespearian for some time, conceived the idea of editing the works, and engaged in an agreement with the bookselling firm of Jacob Tonson to produce an annotated edition. Kenrick was consequently infuriated when Johnson's edition appeared in I 765. Kenrick had already taken a number of subscriptions for his work, and when news reached him that Steevens had issued proposals for still another edition, he was

${ }^{17}$ Sewall, p. $58 . \quad{ }^{18}$ Monthly Review, XXV (1762), 260.

${ }^{19} \mathrm{Ibid}$., XXVII $(1763), 213$. 
unable to restrain himself. He took his revenge against Johnson in a long exposure of Johnson's inadequacies, entitled A Review of $D r$. Johnson's Nerw Edition of Shakespeare: in which the Ignorance, or Inattention of that Editor is Exposed (London, I 765). In this book, Kenrick assumes the rôle of a stout defender of Shakespeare against the clumsiness and ineptitude of Johnson; throughout the work, he affects to be making the attack only in the interest of defending Shakespeare's maligned reputation. Kenrick advances his conviction that "the republic of letters is a perfect democracy"20 which can tolerate no such dictators as "Doctor Johnsonius Obstinatus." ${ }^{21}$ Kenrick then simply proceeds through Johnson's edition, commenting sarcastically on Johnson's restorations, emendations, and exegetical remarks. Kenrick favors a more imaginative interpretation of Shakespearian imagery, and a less precise tracing of connotation than Johnson's. Although Kenrick is unable to resist sneering at Johnson's pension, he is forced to pay high tribute to Johnson the prose stylist, calling him "the best writer in Christendom."22 Although Kenrick wearied of baiting Ursa Major after ploughing through only three of Johnson's volumes, there is evidence in Kenrick's work of the seeds of an enthusiastic Shakespeare idolatry. The book concludes with an advertisement of a promised work which never appeared but which, we may be sure, would not have increased Kenrick's popularity: $A$ Ramble through The Idler's Dictionary, in which are picked up Several Thousand Etymological, Orthographical, and Lexicographical Blunders. If the sarcasm and ill manners can be disregarded, Kenrick's corrections of Johnson are, in the main, sound and justified; Kenrick's attacks on Johnson's hyper-literal approach may have contributed not a little to Shakespeare's appearance to the eighteenth century as "fancy's child." As Brewer has said, Kenrick's Review is

the work of an acute Shakespearian critic, and were it not for the indecent rudeness of its tone, it would be a thoroughly edifying bit of textual criticism. ${ }^{24}$

The Review was the first of Kenrick's productions in years to which he chose to affix his real name. Johnson was stoically unperturbed by the attack, remarking to Boswell that "attacks on authors did them

20 Page $x . \quad 21$ Page i27. 22 Page 54.

${ }^{23}$ Robert W. Babcock, The Genesis of Shakespeare Idolatry, r766-I799 (Chapel Hill, I 931 ), p. 124.

${ }^{24}$ Page 104. 
much service." When an Oxford undergraduate, one James Barclay of Balliol, hastened to Johnson's defense in a pamphlet abusing Kenrick, Johnson expressed irritation at "the boy" for taking so much notice of a mere pest. ${ }^{25}$ On another occasion, Johnson observed, "Sir, [Kenrick] is one of the many who make themselves publick without making themselves known."26

In the next two years, Kenrick made another attempt at playwriting, and in the year I 766 published Falstaff's Wedding: $A$ Comedy, Being a sequel to the Second Part of the Play of King Henry IV. Written in Imitation of Shakespeare. This play, which ran only one night despite generally favorable reviews, was the first Shakespearian "sequel" to be written in the second half of the eighteenth century. ${ }^{27}$ This Shakespearian imitation was followed in 1767 by The Widowed Wife, $A$ Comedy, which was acted at Drury Lane for fourteen nights, and which proved to be one of Kenrick's most successful dramatic efforts.

In 1769 , Kenrick wrote a series of private letters to his lifelong friend Jack Wilkes, begging for permission to use some Pope material in Wilkes's possession ; $^{28}$ Kenrick was projecting an edition of Pope, but, for some reason, Wilkes chose to place the material at the disposal of Joseph Warton, and Kenrick the editor was frustrated again.

Kenrick in I 770 applied himself to a study of perpetual motion machinery, wrote one book on the subject, ${ }^{29}$ and delivered a series of "lectures" at the Devil Tavern; Brewer has wondered whether Kenrick's interest in the subject was a jest, the result of serious curiosity, or merely an attempt to take financial advantage of a topic which the public would pay to read and hear about. ${ }^{30}$ Whatever his motive, Kenrick was actually granted a patent by the Attorney General for a machine he had made in his spare time.

${ }^{25}$ F. A. Pottle and C. H. Bennett, edd., Boswell's "Journal of a Tour to the Hebrides with Samuel Johnson, LL.D." (New York, 1936), p. 238.

${ }^{26}$ G. B. Hill, ed., Boswell's Life of Johnson, rev. L. F. Powell (6 vols: Oxford, 19341950), I, 498.

27 Babcock, p. 33.

${ }^{28}$ This Kenrick-Wilkes correspondence, which has never been published, is to be found in Brewer's MS.

${ }^{29}$ An Account of the Famous Wheel of Hesse Cassel, Invented by Orffyreus, with Remarks on its Utility, Reconstruction, etc. This book is reviewed skeptically in Gentleman's Magazine, XL (I770), 470 .

so Page 143. 
Kenrick on the subject of sexual morality would almost certainly have made an interesting exhibit, and it is with some regret that one discovers that his Free Thoughts on Seduction, Adultery, and Divorce (London, I 77I) is so rare that no library apparently owns a copy.

Kenrick's failures and disappointments influenced him as never before from $\mathbf{I} 770$ on, for, after that date, he seems intentionally to cast aside all pretense to dignity and restraint. Although Kenrick was granted the degree of LL.D. from Marischal College, Aberdeen, in $I 772,{ }^{31}$ he appears not to have considered it an adequate recognition of his powers, and after receiving the degree his

normally egotistical disposition became positively arrogant, and the long and carefully suppressed desire to smite his enemies was almost an irresistible temptation. ${ }^{32}$

Kenrick's first object of attack after receiving his degree was Garrick, with whom he had had frequent disagreements about the production of his plays. Isaac Bickerstaffe, a hack playwright and half-pay officer of Marines, had recently fled to France to escape hanging for sodomy. ${ }^{33}$ Bickerstaffe had of course been friendly with Garrick and with the other theatrical managers; by twisting the implications of the friendship between the two men, Kenrick hoped to make some money and avenge himself on Garrick besides. In 1772 , accordingly, Kenrick published anonymously a long leering poem in heroic couplets entitled Love in the Suds: Being the Lamentation of Roscius for the Loss of his Nyky; while making utterly unfounded insinuations about Garrick's relationship to Bickerstaffe, Kenrick is able to take side swipes at Baretti, Johnson, and Goldsmith. For his trouble, Kenrick was rewarded by becoming known in London as "the malignant, obscene, and leprous creature." ${ }^{34} \mathrm{He}$ later confessed to a friend, it is said, that he had perpetrated the attack simply "to plague the fellow [Garrick]." "35 Garrick immediately entered an action for libel, and when Kenrick discovered that it would require either a duel or a retraction to satisfy Garrick out of court, he prudently published a retraction, which appeared in the St. James's Chronicle (Nov.

${ }^{31}$ McCusker, p. 9. $\quad 32$ Brewer, p. 148.

${ }^{33}$ Joseph Knight, David Garrick (London, 1894), pp. 261 ff.

${ }^{34}$ Ibid., p. 262 . See also "Ariel," The Kenrickad (London, 1772 ), a poem in defense of Garrick which presents Kenrick surrounded by his Four Muses: Envy, Slander, Brandy, and Porter.

${ }^{35}$ Knight, pp. 263-264. 
26, I772). Garrick promptly cancelled the court proceedings, but Kenrick was never able afterwards to live down the labels of libeller and coward.

After another play (The Duellist, A Comedy [London, I773]), which enjoyed little success and in which he found an opportunity to attack Garrick again, Kenrick confidently took upon himself the office of lexicographer. His New Dictionary of the English Language (London, I773), dedicated to, of all people, the King, was one of the first dictionaries in English to indicate pronunciation. Kenrick's prefatory statement,

... the reader will find that $I$ have generally followed the celebrated dictionary of the learned Dr. Johnson, ${ }^{36}$

is perhaps more strictly true than Kenrick intended; since it is difficult to imagine the impatient Kenrick laboriously making separate slips of paper for each entry, as Johnson did, or having anywhere near the means to pay assistants to help him with the job, it will perhaps not be missing the mark very far if we picture Kenrick sitting down, brandy near at hand, with Johnson's two volumes, deleting for the printer as many of Johnson's more abstruse entries as would be necessary to reduce Johnson's two volumes to one, and then simply writing his numbers indicating vowel sounds above each of Johnson's syllables.

A comparison of the definitions in the two dictionaries reveals that, with very few exceptions, Kenrick allowed Johnson's to pass unaltered into his work. ${ }^{37}$ In simply copying Johnson's definitions, Kenrick also, perhaps unwittingly, allowed some of his model's whimsy and prejudice to infuse the "new" work. ${ }^{38}$ Kenrick announced in his preface that his intention was to fix the standards of pronunciation in

${ }^{36}$ Page viii.

${ }^{37}$ The Whig Kenrick, however, was sufficiently alerted against Johnson's Toryism. When Kenrick came to Johnson's definition of Whig as "the name of a faction," he substituted "The name of a party, ... derived from wiga, Sax. signifying a hero, a man of intrepidity, and independency." Similarly Kenrick changed Johnson's "Tory: one who adheres to the ancient constitution of the state, and the apostolical hierarchy of the church of England" to "Tory: the name given to a political partisan in England, opposed to another party who are called whigs. The tories are advocates for ecclesiastical tyranny and arbitrary power; whereas the whigs entertain more popular and republican principles." It is also worth noting that Kenrick permitted Johnson's "a harmless drudge" to vanish from his definition of lexicographer.

${ }^{38}$ Among others, the following are unchanged in Kenrick's dictionary: oats, patron, network, grub-street, poetess, and pension. 
London, especially for the benefit of non-native speakers of English, and it is not difficult to believe that the dictionary actually did help achieve this end. The dictionary is of course valuable to the modern scholar in ascertaining eighteenth-century pronunciations, for example, join as jine and George as Jawge.

From March to June of i 764, Kenrick had helped another hack, Robert Lloyd, edit The St. James's Magazine, and, a year after the publication of Kenrick's dictionary, he took it upon himself to give the world a posthumous edition of Lloyd's poems. Lloyd's verse, consisting mostly of octosyllabic Swiftian satires, is without merit, and his only real claim to literary honors, besides the fact of friendship with Wilkes, Kenrick, and Churchill, is that, according to the admiring Kenrick, Lloyd possessed the enviable ability to begin writing a poem while sober, to get drunk with the poem but partly finished, and then to be able to complete the poem in exact accordance with the original design on the morning after.

In the same year that Kenrick commemorated his late friend's prowess, he inaugurated a series of Shakespearian lectures at the Devil Tavern, partly intended to recompense the subscribers to his abortive Shakespeare edition, and partly, one suspects, to exhibit to the public his knowledge of Shakespeare.

Kenrick's lectures, anticipating those of Coleridge and Hazlitt, were the first public Shakespearian lectures delivered in England, ${ }^{39}$ and after he had tired of the project and had abandoned it within the year, he published his lectures under the title Introduction to the School of Shakespeare (London, I774). A look at some of Kenrick's points may help show to what extent he was imbibing contemporary critical doctrine, and how he was also preparing the way for later interpretations of Shakespeare as unaccountable genius and moral philosopher.

Kenrick stresses Shakespeare's universality and declares himself desirous of pointing out only the poet's "beauties." The actor must enter into and interpret his part by a process of active sympathy, Kenrick maintains, and he goes on,

... my design is in part to explode the mechanical emphasis [in speaking verse on the stage] as altogether improper. It is the habitual exercise of this mode of declamation that misleads the actor from the meaning of the author. ${ }^{40}$

${ }^{39}$ Babcock, pp. 37-38.

40 Page 22. 
Kenrick considers Shakespeare a supreme moral philosopher, and states that Shakespare's moral system has

... perhaps contributed more to form our national character, for humanity, justice, and benevolence, than all the theoretical books of morality which have appeared in our language. ${ }^{41}$

Although Kenrick is a long way chronologically, intellectually, and morally from Coleridge and Hazlitt, it is interesting to look forward to the emphasis placed by those later lecturers on sympathetic identification with Shakespeare's characters and on the perfection of Shakespeare the moralist.

Brewer has conjectured that after I774, Kenrick's mind was warped toward a mild form of pathological megalomania; ${ }^{42}$ he now relied heavily on brandy to allay the pains of his gout. ${ }^{43}$ It had been his lifelong ambition to edit his own critical monthly, and in 1775 he became editor (and chief writer) of The London Review of English and Foreign Literature; he had been planning this review since his days of servitude under Griffiths, and it was his intention that The London Review become a formidable rival of both the Monthly and the Critical reviews. He continued editing this review until his death, ruling his stable of hacks "as an emperor," his death to his son, William Shakespeare Kenrick. Kenrick was not above using The London Review to carry on vigorous acts of vengeance against some of his earlier enemies, and his natural love of philosophical and theological dispute provided him with a number of fresh foes. His obsession during these last years, frequently broadcast from the pages of his review, was his old notion that the mere human rational faculty is insufficient for apprehending religious truth.

After one last violent attack upon Soame Jenyns for daring to state that reason is a fit instrument for the performance of sacred offices, ${ }^{45}$ and after the decrescendo of a neo-Fletcherian comic opera (The Lady of the Manor [London, I778]), Kenrick died in I 779 at the age of 49 . As Alexander Chalmers (or one of his employees) put it, Kenrick was

\footnotetext{
${ }^{41}$ Page 1 5. ${ }^{42}$ Page 1 $96 . \quad{ }^{43}$ McCusker, p. 1 o.

44 Brewer, p. 208.

${ }^{45}$ In Observations on Soame Jenyns's View of the Internal Evidence of the Christian Religion (London, 1776).
} 
... less lamented than perhaps any person known in the literary world, yet possessed of talents which, under a steady and virtuous direction, might have procured him an honourable place among the authors of his time. ${ }^{46}$

I have tried to give an idea of the whole career of William Kenrick, the hack, the dramatist, the lexicographer, the Shakespearian, and the "superlative scoundrel." Kenrick of the Monthly Review, and, from an examination of some of Kenrick's reviews of contemporary works, attempt to suggest his general critical position.

The bulk of the criticism in Kenrick's reviews is judicial; he usually concerns himself with pointing out merits and defects, and with trying to reach a final decision about the permanent value of the work in question and about its comparative rank among other works of the same genre. Kenrick, like Dick Minim, generally takes a common-sense critical position; he insists that style be adjusted to subject, he invokes "the rules" when a particular production seems to him to beg for judgment under their jurisdiction, he places a high premium upon originality, and he shows, as one might expect, a strangely acute ability to detect hasty or shoddy work.

Kenrick's review of Tristram Shandy is one example of his good sense and taste as an evaluative critic. One of his points would, I think, find quite a bit of agreement today; he calls attention to

... a certain quaintness, and something like an affectation of being immoderately witty, throughout the whole work.

The reviewer, however, despite this slight complaint, recommends the book highly, and concludes that the author is

... a writer infinitely more ingenious and entertaining than any other of our present race of novelists. ${ }^{48}$

Kenrick's review of Macpherson's Fragments of Ancient Poetry ( 1760 ) is also of some interest. Although the reviewer began to suspect the fraud at a later date, he seems to have considered the fragments genuine at this time. Kenrick comments on the simplicity of metaphor in the "poems," and delivers a judgment that some of

${ }^{46}$ Alexander Chalmers, ed., The General Biographical Dictionary ( 32 vols. : London, $1815), X I X, 327$.

${ }^{47}$ Gordon Goodwin, in $D N B$.

${ }^{48}$ Monthly Review, XXI (1759), 568, 57 1. 
his contemporaries more inclined to primitivism might profitably have heeded:

... striking as the stile and manner [of early poems in general] may be to common readers, they are too often attended with such gross improprieties and tautologies, as make even their greatest beauties disgusting to persons of the least taste or critical knowledge. ${ }^{49}$

Kenrick is somewhat more kind to Macpherson's Fingal, praising its "extraordinary merit," but insisting that, since the poem can fit only under the general heading of epic poetry, it must be judged by principles derived from previous successes in that form:

The noble flights, and native excursions, of true genius are, indeed, frequently too eccentric to be exactly measured by critical rules; ... it is expedient, nevertheless, that the mechanism and execution of every considerable performance should be compared with that standard, and examined by those laws, which have, for many ages, been allowed to constitute the perfection of that particular species of writing, under the denomination of which such performance is presented to the world. Criticism degenerates, otherwise, into a servile echo of the leading voices of the times, and gives encouragement for every rising genius to indulge the luxuriance of his imagination, at the hazard of being hurried into bombast, extravagance, and absurdity. ${ }^{50}$

Kenrick's insistence on the application of universally valid standards to guard against the prejudices of one's own time and place is a reminder that, despite his pertness and impetuosity, his criticism generally rests on the same firm, humanistic foundation which Johnson and Reynolds employed to secure their judgments against the fashions of temporary taste. Kenrick shows concern over Macpherson's having classed the production as an epic, and fears that such inexact labeling may tend to violate the traditionally strict boundaries separating the genres. Kenrick admits that a sort of romantic crudeness is always necessary in epic, and that it benefits from

... obscurity [that] will excite in us a kind of veneration, which precise ideas, correct imagery, and perfect similitude of allusion could never inspire. ${ }^{51}$ After judicially weighing the poem's merits and faults, Kenrick concludes that it is indeed a great curiosity, but stands as a dwarf next to Homer and Virgil.

${ }^{49}$ Ibid., XXIII (1 760), 205.

51 Ibid., p. 44 .

${ }^{50}$ Ibid., XXVI (1762), 4 I. 
In his review of Percy's Reliques, Kenrick praises the simplicity of the pieces, but mocks the absurdity of modern efforts to duplicate primitive simplicity. Kenrick seems able to recognize the difference between this collection of genuine pieces and Macpherson's Fragments, for he accords the poems high praise, comments on their many "artless graces," and concludes,

... we are far from thinking . . . with certain tasteless readers, that there is not merit in the compositions themselves. ${ }^{52}$

Kenrick's periodical review of Johnson's edition of Shakespeare, which provided the impetus but not the basic pattern for his later book, is a rare amalgam of malice, envy, bad manners, and sound, temperate criticism. Kenrick begins by expressing anger that Johnson, instead of pointing out "beauties," had restricted himself to mere annotation and elucidation. He ascribes this failure of Johnson's to "the extreme indolence of the Writer; who is naturally an idler." After a few more thrusts at Johnson's "want of ingenuity" and "pompous style," Kenrick settles down to some genuine criticism of the preface to the edition. Johnson in his preface had listed as defects, among other failings, Shakespeare's frequently strained wit and his excessive dalliance with "quibbles"; Kenrick rises angrily to Shakespeare's defense, labels Johnson's censures "harsh and severe," and seeks to defend Shakespeare from Johnson's criticism by asserting that these faults of Shakespeare's were due, not to the man, but to the natural "barbarity of his age." Kenrick then employs the venerable tu quoque argument, pointing out that these "faults" of Shakespeare are also to be found displayed in the works of Samuel Johnson.

In his preface Johnson had defended Shakespeare's freedom with the unities by saying that, since the spectators are undeceived as to the reality of the action being represented before them, disunities of time and place violate no sense of reality, and are hence permissible, if the unity of action be maintained. Kenrick, while agreeing with Johnson's motive in "excusing" Shakespeare, finds fault with Johnson's method of defense. It is here that we may observe Kenrick applying sound common sense to the problem, and he does, I think, make a just improvement on Johnson's theory. Kenrick says,

${ }^{52}$ Ibid., XXXII (1765), 242 . 
The dramatic unities, if necessary, are necessary to support the apparent probability, not the actual credibility of the drama.

Kenrick can find no other reason for the emotional effect of the action on the spectator, and the spectator's willing involvement in what he knows to be merely a represented action, than a deception of the senses, but not of the reason:

The spectator is unquestionably deceived, but the deception goes no farther than the passions, it affects our sensibility but not our understanding: and it is by no means so powerful a delusion as to affect our belief.

Kenrick thus takes a middle position between a claim for total dramatic deception and a claim for no deception at all. It is, after all, difficult to account for the inevitable emotional involvement of the spectator in stage action (and even laughter at represented folly suggests emotional involvement) unless one is prepared, with Kenrick, to admit a willing deception of the senses, even though the rational faculty remain sceptical.

That Kenrick, despite his rages and his sarcasms, possessed a keen sensitivity and a shrewd ability to divine Johnson's condition of mind from the tone of his prose at any time may be observed in his writing that the whole preface seems to be

... the production of a wavering pen, directed by a hand equally wearied and disgusted with a task, injudiciously undertaken, and as indolently pursued..$^{53}$

If the great Cham read this review, this last remark, together with Kenrick's earlier thrust at Johnson's indolence, must have given him at least a momentary sting of embarrassment, and that a person of Kenrick's position and reputation could perceive the secret concealed behind Johnson's manly prose must have struck Johnson as somewhat uncanny.

So much for Kenrick the critic. Posterity has not dealt kindly with William Kenrick, and perhaps with justice. Few, however, would care to go as far in condemnation as one Cuthbert Shaw ("Mercurius Spur") did, when he wrote the following lines:

Dreaming of genius which he never had,

Half wit, half fool, half critic, and half mad:

... Eager for slaughter, and resolved to tear

${ }^{53}$ Ibid., XXXIII (1765), 285-301; 374-389. 
From others' brows the wreath he must not wear,-

Next Kenrick came: all furious, and replete

With brandy, malice, pertness, and conceit;

Unskill'd in classic lore, through envy blind

To all that's beauteous, learned, or refined. ${ }^{54}$

It would perhaps be more just to agree with an early nineteenth century biographer, who wrote:

Dr. Kenrick was really a man of talents, and deficient only in the knowledge of making a proper use of them; it was his misfortune also to settle upon no regular plan of study. ${ }^{55}$

Although sociological and environmental defense of petulance and outrage has its dangers, a recognition of Kenrick's poverty throughout his life may help explain, if not excuse, his frequent expression of envy of the more brilliant and malice towards the more fortunate. His efforts to carve a lasting reputation for himself are, when all has been said, more pathetic than despicable. His whole career, whether we attend to the early years represented by The Pasquinade or to the later years in which he performed primarily as critic rather than satirist, suggests that the English eighteenth century (and Kenrick is by no means an unrepresentative figure) is inadequately apprehended if a modern observer permits himself to dwell excessively on such productions of the age as Handel's majestic music, Gray's mannerly poems, or Reynolds's gentlemanly paintings. Beneath the famous veneer of civility, poise, and measure, individual personalities were in a painful ferment of rage and frustration. It is the violent and twisted world of Richard Savage and the angry and bitter young Johnson, rather than the amiable milieu of Chesterfield and Beau Nash, which revives in our imaginations when we open in New Jersey, at a distance of two centuries, the battered little Remarkable Satires, a pathetic memorial of a bitter and disappointed human life.

${ }^{54}$ Quoted by James Prior, The Life of Oliver Goldsmith, $M . B$. (2 vols.: London, I 837$),$ I, 295-296.

${ }_{55}$ General Biographical Dictionary, XIX, 324. 